\title{
GOMBOCZ ESZTER*
}

\section{Cserkészliliom és kőtábla}

\section{A zsidó identitás újjáépítésének törekvései a két világháború közötti neológiában Vidor Pál életének példáján}

„A cserkészruha fölé huzza a rabbi-reverendát, ha egyet mozdul, kilátszik a bakkancsa és a meztelen térdei."1

\section{Bevezetés}

\begin{abstract}
Trianon után összezsugorodott Magyarországon a zsidó A felekezetek/irányzatok között domináns helyzetbe került neológia korábbi, évtizedeken át folytatott asszimilációs stratégiája hirtelen nemkívánatossá vált a többségi magyar társadalom szemében. A 19. század végére látszólag sikeresen integrálódott zsidóságra mind nagyobb nyomás nehezedett a hol nyíltan, hol burkoltan megnyilvánuló antiszemitizmus következtében. A másik kihívást a neológ irányzat számára a városi lakosságot jellemző fokozódó szekularizáció jelentette. A kettős szorításra a neológia a hagyományos, ,zsidó vallású magyarok vagyunk” önmeghatározástól
\end{abstract}

\footnotetext{
* A szerző a Wesley János Lelkészképző Főiskola (Budapest) és az Apor Vilmos Katolikus Főiskola (Vác) tanára. E-mail: gomboczeszter08@gmail.com

${ }^{1}$ Egy lelkes szülő elismerő szavai ezek Vidor Pálról a gödöllői világtábor után. L. Szabolcsi Lajos: Péntek esti istentisztelet a gödöllöi park fái alatt. Egyenlöség, 1933, 42. Nyitó oldal. Az idézetet megelőző rész így hangzik: „,Vidor Pál nem is Pál és nem is doktor, hanem egyszerüen Pali, mert a 7 éves farkaskölyköktől kezdve mindenki tegezi őt és mindenkit tegez ő is. Ott lakik egy kis sátorban, a budai cserkészcsapat tagjai között, a fiukkal virraszt, a fiukkal gyakorlatozik, velük él és érettük dolgozik."
}

REGIO 27. évf. (2019) 2. szám 105-126. 
a disszimiláció különböző fokozataiig terjedően igen széles skálán válaszolt. $^{2}$

A válaszkísérletek egyik fő jellemzője a zsidó öntudat erősítését célzó törekvés, amely hol a zsidó vallás és/vagy a zsidó kulturális értékek megtartó erejének újraélesztésében, hol a harcosabb öntudat/nemzettudat táplálásában, hol egyszerre mindkettőben nyilvánult meg. Az első változatot képviselte a Léderer Sándor ${ }^{3}$ által meghirdetett, „Vissza a zsidósághoz” típusú disszimilációs stratégia, illetve az immár időszerütlennek tartott, mind teljesebb beilleszkedési törekvést leváltó ún. „kultúrnacionalizmus” programja (Komlós Aladár, Patai József). Az utóbbi a dualizmuskori asszimilációs modellt igyekezett módosítani a zsidó kultúra iránti érdeklődés felkeltésével. ${ }^{4}$ Mindezzel szemben Vázsonyi Vilmos, a Demokrata Párt alapítója úgy helyezte új alapokra a zsidó identitást, hogy egyfajta konstruált magyar történelemképre támaszkodott. Ennek középpontjában a liberális Magyarország monarchiabeli emancipációs gondolata állt, melyhez Vázsonyi szerint igenis hü maradhat a magyarországi neológia. Deák, Kossuth, Eötvös szabadelvüségére hivatkozott: „, A szabadelvüségnek ez a tüze nem fog kihalni soha a magyar nemzetböl.... Mi zsidók, a kultúra höméröje vagyunk. Ahol bennünket üldöznek, ott nincs szabadság, kultúra, ott nincs élet."

Az eddigiekben említett különböző stratégiák a zsidó cserkészeten belül is nyomon követhetőek. A két világháború között Magyarországon kibontakozó cserkészcsapatok ugyanis természetes közeget képeztek a tájékozódási pontokat kereső zsidó fiatalok számára. Az alábbiakban az adott időszakban megjelent zsidó sajtóorgánumoknak (Egyenlöség, Magyar-Zsidó Szemle, évkönyvek, cserkész csapatújságok) azon részleteiből szemelgetek példákat, amelyek a budai 311-es számú Vörösmarty cserkészcsapat tagjainak cikkeiből, illetve Vidor Pál tudós rabbi írásaiból olvashatók ki a

${ }^{2}$ Frojimovics Kinga: Szétszakadt történelem. Zsidó vallási irányzatok Magyarországon 1868-1950. Budapest: Balassi Kiadó, 2008. 227. skk.

${ }^{3}$ A Pesti Izraelita Hitközség 1921 és 1927 közötti elnöke.

${ }^{4}$ Frojimovics Kinga szerint a kultúrnacionalizmus magyarországi változata ugyanazt célozta, mint Közép-Kelet-Európa más országaiban a cionisták által „galut-munkának” nevezett tevékenység kulturális része: a zsidó élet, identitás megteremtését. L Frojimovics, 2008. 259.

${ }^{5}$ Vázsonyit idézi Frojimovics, 2008. 251.

REGIO 27. évf. (2019) 2. szám 105-126. 
témával kapcsolatban. A „belső” közönségnek szóló csapatújságok, csapatnaplók vizsgálatát azért tartom fontosnak, mert ezeken a fórumokon keresztül a zsidó-magyar együttélés őszinte, hétköznapi, kozmetikázatlan elemei is megragadhatóak.

\section{A Vidor-modell és annak háttere}

Dr. Vidor Pál ${ }^{6}$ rabbijelöltként, majd 1934-től már rabbiként tudományos tevékenysége mellett több úton, tudatosan igyekezett megszólítani a zsidó identitást újraépíteni kívánó fiatalokat. Egyrészt a Budai Izraelita Hitközség Ifjúsági Csoportjának ügyvezető titkáraként, másrészt a zsidó cserkészeten keresztül, elsősorban az 1933-as gödöllői világtalálkozó előkészítése, majd megvalósítása során, legfőképpen pedig saját példamutatásával a cserkészekkel közös tábori életben.

Vidor elgondolásában a hitközség feladata, hogy a vallási közömbösség terjedésének ellenszereként tudatosan segítse az ifjúságot a zsidóság megismerésében. ${ }^{7}$ Ezt - nyilvánvalóan nem egyedül - egy budai ifjúsági kulturális csoport létrehozásával valósította meg már a 30-as évek legelején. A csoport amolyan szabadegyetemként müködött. Az ifjúsági csoport 1931-ről szóló jelentésében Vidor arról számol be, hogy a tudomány, a művészet, az irodalom müvelése közepette összetartozás, barátság fejlödik ki a tagok között, ami „ifjúságunk társadalmi egységét is megerősítette.”8 Ebben az évben, azaz 1931-ben 27 összejövetelt rendeztek érettségi

\footnotetext{
${ }^{6}$ Dr. Vidor Pál 1909-ben Budapesten született. Családjával együtt 1936 óta lakott a mai Frankel Leó út 49. számú házban, amely évtizedeken át a Vörösmarty cserkészek otthona volt. Innen vonult be - utoljára 1942-ben - munkaszolgálatra, ahonnan soha többé nem tért vissza családjához. A 30-as évek első felében Vidor gyakran publikált a Magyar-Zsidó Szemlében, a Zsidó Életben és más zsidó sajtótermékekben. 1934. március 22-én avatták rabbivá. Beszéde az 1934-1935. évi Magyar-Zsidó Szemle „Jabneh” (Homiletika) rovatában jelent meg Chóréb ormán címmel. A hatásosan megfogalmazott szöveg a szerző mély szentírási és szépirodalmi tudásáról tanúskodik. Vidor a cserkésztáborok megszervezésében is aktívan részt vett, sőt a tábori istentiszteleteket is ő vezette. Vö. Hrotkó Larissza: Vidor Pál ürügyén.,,A Chóréb ormán”. Remény, 2007. 1.

${ }^{7}$ Benoschofszky Imre - Vidor Pál (szerk.): Évkönyv. A Budai Izraelita Hitközség Kulturális Szakosztálya Ifjusági Csoportjának 1930/31 évi müködéséről. Budapest, 1931. 7.

${ }^{8}$ Vidor Pál: Csoportunk mult évi munkássága. In: Évkönyv, 1931. 3.
} 
után lévő jelentkezőknek, és nyolc előadásból ${ }^{9}$ álló sorozat keretében igyekezték őket bevezetni ,a zsidó szellem lényegének és történetének ismeretébe." 10

Vidor pozitív hangnemben, az eredmények tudatában fogalmaz: „Ifjúságunknak egy jelentős és értékes rétege igenis »keresi« az utat a zsidóság felé." "11 Goldzieher Ignácra hivatkozik: tudás nélkül csak »buzoghatunk«, de nem »lelkesedhetünk «. ${ }^{12}$ Dr. Kriszháber Adolf hitközségi elnök javaslatára azt tervezik, hogy a magyarországi zsidó történelem [feltételezett G. E.] folytonosságát egyértelművé tegyék, és ezáltal a zsidó identitást erősítsék. Ennek érdekében fiatalok kutatnák és rendszereznék a budai zsidóság nyolc évszázados történetét. ${ }^{13}$ Vidor egyben arról is szól, hogy a budai hitközség ifjúsági csoportjának sikerei az egész ország számára pozitív például szolgálhatnak. ${ }^{14}$

Vidor Pál tehát elszántan küzdött egy új nemzedék fölépítéséért, dacolva a korabeli elkeseredett hangulattal. A felekezeti sajtó 1930 körül valóban tele van panasszal: a fiatalok semmit sem tudnak a zsidóságról, a héber tanulása akadozik, a heti két hittanóra pedig kevés az ismeretek átadására. ${ }^{15}$ Végiggondolt tantervre lenne szükség. Másrészről a szülők sem igazán motiváltak, a legtöbb városi család asszimilálódik.

A fentebb több helyen idézett Évkönyv 1930/31. évi jelentésében Hajdú László a zsidó fiatalok kisebbrendüségi érzését, a

${ }^{9}$ Az előadások során Patai Éva a „feltámadó szentföldet” mutatta be. Beszámolt Palesztina iskolaügyéről, a gyermekkertkultúráról, a gyermektelepekröl, a jeruzsálemi egyetemről, illetve saját élményeiről. De szépirodalmi és filozófiai müvekről is folytattak vitát (Arnold Zweig, Jakob Wassermann, Kant). Széles spaletta ez, nem korlátozódik sem a vallásra, sem a zsidó kultúrára, sem a cionizmus terjesztésére. Sokoldalú mủveltséget szeretne nyújtani, miközben a vallási rutinnak is teret enged.

${ }^{10}$ Vidor, 1931. 3.

${ }^{11}$ Uo. 7.

${ }^{12}$ Uo. 7.

${ }^{13}$,Szimbóluma lesz ez annak, hogy ifjúságunk érdeklödik a zsidó mult iránt és kapcsolatot keres a zsidó jelennel, szimbóluma annak, hogy a gondolatok és eszmék láncolata nem szakad meg, hanem tovább halad rajtunk keresztül a távol jövendö felé” Uo. 7.

${ }^{14}$ A folyóiratokat mindenütt betühíven idézem - a szerz. megj.

${ }^{15}$ Vö. Munkácsi Bernát: Az izraelita vallásoktatás újabb országos rendezésének elömunkálatai. Budapest, 1930.

REGIO 27. évf. (2019) 2. szám 105-126. 
Minderwertigkeitsgefühl járványát tartja az egyik fó problémának. ${ }^{16}$ Míg a zsidó értékekről semmit sem tudnak a fiatalok, addig nem zsidó részről állandó nyomásnak vannak kitéve, így zsidóságukat leginkább csak akadálynak élik meg. Ennek egyedüli ellenszere a zsidósághoz való visszatérés: „vissza a zsidó társadalomhoz és a zsidó kultúrához" ${ }^{17}$ Hajdú László, amint azt a 311 . Vörösmarty csapat jubileumi kötetéből (1924-1934) megtudhatjuk, maga is cserkész, illetve cserkészraj vezető volt Schächter Imre (Kaba) mellett. Feltehetően Vidor Pál hívta a cserkészetbe a tehetséges fiatalt.

A családi háttérre vonatkozóan dr. Benoschofsky Ilona végzett egy kisebb iskolaszociográfiai vizsgálatot az 1930-as évek közepén a budai középosztály körében. ${ }^{18}$ Benoschofsky két, előkelő budai negyedben elhelyezkedő gimnázium felső osztályaiból választott ki tetszőlegesen száz zsidó családot, amelyek sokszobás lakásban, jó anyagi körülmények közepette éltek. A zsidósághoz való kötődési pontokat keresve egy ranglistát állított föl. Az átlag budai család péntek esténként gyertyát gyújt (58\%), eljár templomba (péntek este $34 \%$ ), mezuzát függeszt ki ajtajára. Kiddust már sokkal kevesebben tartanak (14\%), havdolót még kevesebben. „Havdolót 55 gyermek soha nem látott még, a többi nagyszülöknél, templomban, vagy cserkésztáborban látott ugyan, de otthon mindössze 7 család választja el ünnepélyesen a szombatot a hétköznaptól." ${ }^{19}$ Kóser háztartást 16 család tart. 75 fiú közül reggelenként, iskolába indulás elött mindössze tízen imádkoznak rendszeresen taliszban és tefilinben. 26-uk szülei eleve nem kötöttek egyházi házasságot, ők már aligha kötődnek a zsidósághoz. Ünnepnapokon javul a statisztika, ekkor 66\%-uk jár rendszeresen templomba. Sokaknál az egyik utolsó kötelék a böjt és a halottakra emlékezés: „Mert ha valaki semmi mást nem tart meg zsidóságából, csak azt, hogy Jaum Kippurkor böjtöl és imádkozik, vagy mazkirkor megemlékszik a halottjairól, az még zsidó.” ${ }^{20}$

\footnotetext{
${ }^{16}$ Hajdú László: Néhány szó a modern zsidó ifjúság kérdéséhez. In: Évkönyv, 1931. 9-10.

${ }^{17}$ Uo. 10.

${ }^{18}$ Benoschofsky Ilus: Száz budai zsidó család. In: Benoschofsky Imre - Vidor Pál (szerk.): Évkönyv. A Budai Izraelita Hitközség Kulturális Szakosztálya Ifjusági Csoportjának 1936 - 38 évi müködéséröl VII - VIII. Budapest, 1938. 9-13.

${ }^{19}$ Uo. 11.

${ }^{20}$ Uo. 12.
}

REGIO 27. évf. (2019) 2. szám 105-126. 
Az utolsó stációnál már pénteki gyertyát nem gyújtanak, és imakönyv sincs a háznál, de a zsidóság sorsáról még tájékozódnak a felekezeti lapokból, például az ingyen kapható Budai Izraelita Hitközség Értesítőjéből (73\%). 17-en fizetnek elő az Egyenlőségre. A könyvek számát vizsgálva az derült ki, hogy azokban a családokban hiányzik föképp a Biblia és az imakönyv, ahol vagy nagyon sok könyv van, vagy nagyon kevés. Benoschofsky végül korrekt módon megjegyzi, hogy a felmérés homogén mintán, egyetlen társadalmi osztály körében történt, így annak eredménye nem általánosítható.

„,...nem lehettek jó cserkészek, ha nem vagytokjó zsidók...”

A föntiekből érthető, hogy az1930-as években a hitközségek, a fiatal rabbik országos törekvése lett a fiatalság megszólítása. ${ }^{21}$ Vidor Pál, a későbbi budai rabbi egyike volt azoknak, akik korán felismerték a cserkészetben rejlő közösségi életforma lehetőségét. Ráérzett arra, hogy a magyarországi cserkészmozgalom két pillére, a vallási és a népi-nemzeti hagyomány egy életképes, rugalmas, mégis megtartó keretet biztosíthat a szekularizáció és az antiszemitizmus kettôs szorításában kizárólag egyfajta identitás mellett nehezen elköteleződő neológia számára.

Vidor a Magyar Cserkészszövetség Kiképző Szabályzatában leírtakkal összhangban kezdettől fogva világosan látta, hogyan lehet a fiatal zsidó cserkészeket leginkább motiválni. Az élményalapú, észrevétlenül ható tanulást valósította meg. Bifláztatás helyett terepre vitte a fiatalokat. Holisztikusan, nem csak kognitív, hanem érzelmi úton is hatott a fiúkra, akik rabbivá avatása elött, 1933-ban nem is sokkal fiatalabbak nála. A próbáztatás is más, mint az iskolai feleltetés:

„A cserkészekkel beszélgetünk, templomban, elöadásokon együtt vagyunk velük, könyveket kölcsönzünk nekik, azután a könyvek olvasása nyomán támadt impresszióikat megbeszéljük. Mire egy-egy próbához eljutnak, anélkül, hogy észrevették volna, a próba egyes tudnivalói már mint elismertek szerepelnek nyilvántartásunkban. A

21 A tematikus blokkhoz tartozó, a zsidó cserkészcsapatok adatait összesítő táblázat jól tükrözi ezt a tendenciát: sok cserkészcsapat hitközségi keretben, hitoktatók kezdeményezésére szerveződött.

REGIO 27. évf. (2019) 2. szám 105-126. 
lelki életben és a nevelés munkájában minden mindennel összefügg. Az egész embert neveljük és igy az értelmi meg érzelmi mozzanatok minduntalan át- meg átjárják, át- meg átszövik egymást. Eddig mégis elsösorban az értelmi neveléssel foglalkoztunk, pedig az érzelmi hatás, a közös imádságok, ünnepélyek, avatások, istentiszteletek, tábortüzek lélekformáló ereje legalább ilyen, ha nem nagyobb jelentöségü. "22

Az 1933-as gödöllöi világtalálkozót Vidor cserkész pályájának csúcspontjaként könyvelhetjük el. Hosszú ideig készült rá szinte gyermeki odaadással, pozitív fordulatot várva tőle. 1932-ben megjelent cikke a budai cserkészek háromhetes szendehelyi táborozásáról, a jamboree-ra való készülődésről szólva a zsidó érzés táplálását szorgalmazta. ${ }^{23} \mathrm{~A}$ tábor során forgószínpadszerüen, 15 perces váltásban folyt a kiképzés (térképolvasás, krumplifözés, iránytü használata stb.): „A forgószínpad napról - napra váltakozó elöadásai között csak egy olyan van, amelyik az egész táboron át folytatódik: a vallási ismeretekkel foglalkozó elöadássorozat." A legfőbb imádságok, az ünnepek jelentőségén túl szóba került a zsidóság története, a zsidóság világhelyzete is: „A cserkészetnek magának is zsidó szinezetet, zsidó veretet adunk." A táborban „Cserkészideálokat választunk a zsidó múltból, az egyik Mózest, a másik Dávidot, a harmadik Juda Makkabit, és a cserkésztörvényeket megvilágítjuk szentírási törvényekkel, szentírási eseményekkel. (...) A zsidó érzést élesztik, a zsidó érzést táplálják hetenként háromszor a tábortüzek is. "24 Vidor tehát nem pusztán zsidó vallásról, hanem zsidó érzésröl is beszél, ami alatt a zsidó identitás megnevezhetetlen örökségére céloz.

Az Egyenlöség 1933-ban megjelent egyik számában a jamboree elött tartott afféle seregszemlét. ${ }^{25}$ A zsidó cserkészet múltját a

${ }^{22}$ Vidor Pál: A zsidó cserkészet (a zsidó ifjúság nevelésének egyik útja). In: Benoschofsky Imre - Vidor Pál (szerk.): Évkönyv. A Budai Izraelita Hitközség Kulturális Szakosztálya Ifjúsági Csoportjának 1933/34 évi müködéséröl. Budapest, 1934. 43-44.

23 Vidor Pál: „Szól a kakas már...” a tábortűz mellett. A zsidó cserkészek táborozása. Egyenlőség, 1932. 42. 6.

${ }^{24}$ Uo. Cikkében az összes, vallásra vonatkozó fogalmat dőlt betűvel emeli ki. A fentieken kívül ezek szerepelnek még: legföbb imádságok, péntek este, a Szombat rejtelmes királynöje, stb.

${ }^{25}$ Vidor Pál: A gödöllői táborozás. Seregszemle a jamboree előtt. Egyenlöség,1933. 39. szám, 11.

REGIO 27. évf. (2019) 2. szám 105-126. 
Kadimah 1926-os felbomlásától áttekintve ${ }^{26}$ az ifjúság kulcsszerepét fejtegeti a zsidó vallás megújulásában a megfelelő bibliai hősökre hivatkozva: „A zsidó vallás a megujhodást, a szebb, boldogabb korok beköszöntését az ifjusághoz füzi. Uj, ifju, szabad és erös nemzedék foglalhatta csak el az igéret földjét. Dániel elött változhatott csak át rózsakertté az oroszlánok verme. Juda Makkabi verhette csak le a sokszoros tuleröt s avathatta, szentelhette fel ujra a templomot. A magyar zsidóság is csak az ifjuságtól - s benne derék, jó munkát végzö cserkészfiainktól - várhatja a jobb jövőnek hajnalsugarait!"27

$\mathrm{Az}$ Egyenlőség évről évre tudósított a világtábor elökészítő munkálatairól, majd két vezércikket is szentelt a gödöllöi találkozónak. ${ }^{28} \mathrm{~A}$ folyóirat a többségi társadalomhoz tartozás bizonyítékaként igyekszik beállítani a zsidó cserkészetet, noha az nem feltétlenül és nem kizárólag az asszimilációs stratégia útján járt. A 41. szám beszámolója hosszasan reklámozza a tábort, amely „eszményi példaképe a társadalmi és felekezeti békének.(...) Ebben a táborban mindenki testvér, ebben a táborban nincsenek elöitéletek és nincsen gyülölködés". ${ }^{29}$ A gödöllöi tábor tehát arra is reprezentációs lehetőséget teremtett, hogy nemzetközi porondon békésnek állítsa be a magyarországi zsidóság és a többségi társadalom kapcsolatát. ${ }^{30}$

A 41. számban megjelent cikk fölsorolja a magyar zsidó csapatokat (a budai, a pesti izraelita hitközség, a MIKÉFE, a szegedi, a debreceni stb. csapatokat), majd méltatja Epstein Tibor monumentális cserkészoltárát, illetve a Tórát, amelyet a gödöllöi izraelita hitközség bocsátott rendelkezésre, és amelyet egy külön díszraj hozott át ünnepélyesen a táborba. A Tórát azok a fiúk szállíthatták jutalmul, akik az aktuális ünnepen a többiekhez képest

\footnotetext{
${ }^{26}$ Lásd a tematikus blokk erre vonatkozó, Bányai Viktória által írt tanulmányát: Liliom és Dávid-csillag: a zsidó cserkészet kezdetei Magyarországon, 1913-1924 ${ }^{27}$ Vidor Pál: A gödöllői táborozás... 1933. 11.

${ }^{28}$ Egyenlöség, 1933. 41. és 42.

${ }^{29}$ Szabolcsi Lajos: A zsidó cserkészek a gödöllői világtáborban. Egyenlöség, 1933. 41. szám. 1-2.

${ }^{30}$ Vidor Pál Szántó Jenőt, az Országos Iroda alelnökét idézi: „, Mikor felekezetünk a jamboree ügyét felkarolta ..., nemcsak zsidó vallási feladatot látott benne, hanem Stern Samu elnökömmel abból indultunk ki, hogy a magyar nemzeti ügynek és missziónak teszünk ezzel szolgálatot. 'L. Évkönyv,1934. 38.
}

REGIO 27. évf. (2019) 2. szám 105-126. 
tovább tartották a böjtöt. ${ }^{31}$ A nyitó istentiszteletet Vidor Pál vezette, majd a prédikációt is ő tartotta a világ minden tájáról, többek között Szíriából is érkező zsidó cserkészeknek. Az Egyenlöség idéz Vidor elragadtatott hangvételü beszédéből is. Az itt kiemelt rövid szakasz a félelem legyőzésére, harcra kész, szilárd tartásra biztatja a zsidó fiatalokat: „Az önérzetes és szilárd, vidám és bátor zsidó fiatalságot köszöntöm bennetek. És ahogyan itt álltok Istennek a gyönyörüséges erdei szentélyében, hallom, amint tihozzátok is szól az Örökkévaló: Cházák veemác! Legyetek erősek és szilárdak, ne féljetek, és ne rettegjetek, én veletek vagyok minden munkátokban, minden utatokban [...] Vivjátok meg harcotokat! Gyülölet ellen szeretettel, közönyösség ellen prófétai hevüléssel. ..."32

A tábori lelkészek, mint a cikkböl értesülünk, vállpántjukon viselték vallásuk jelvényeit: a katolikusok keresztet, a protestánsok a nyitott Bibliát. Vidor Pál kérvényezte a vezetőségnél a kettős kőtábla viselését, amelyre - sajátos módon - átmenetileg engedélyt kapott. Vidor számára tehát a tábori oltár mindenki számára látható kettős kőtábláján kívül az is fontos volt, hogy ő maga is viselhesse a zsidó szimbólumot, bizonyítva saját maga és a világ előtt büszke zsidó identitását. Ugyanezek a jelképek jelentek meg a következő évben, 1934-ben a csapat 10 éves évfordulója alkalmából a Budai Izraelita Nőegylet által ajándékozott új lobogón. Vidor az Egyenlöség hasábjain ismerteti a zászló „mellérendelö” szimbolikáját (liliom és kőtábla): „Egyik oldalát a cserkészliliom, másik oldalát a kettös kőtábla ékesiti, jelképezve a cserkészgondolatnak a zsidógondolattal való szoros, elválaszthatatlan egységét." 33 Azonban hozzáteszi a maga hierarchikus változatú, pedagógiai magyarázatát is: „Nem azt mondjuk a cserkészeknek: ne csak jó cserkészek, de jó zsidók is

31 A cikk a tóratekercs szállításáról idézi a Vidor Pál által megjutalmazott Hochfelder Antal Gábor (Sas Örs) beszámolóját is: Egyenlöség, 1933. 41. 2.

${ }^{32}$ Uo. 2. A világtalálkozóról beszámoló összeállítás részeként arról is értesülünk, hogy a Dohány utcai zsinagógában ünnepi istentiszteletet tartottak, ahol a Pesti hitközség elöljáróinak beszédeit követően, a frigyszekrény megnyitása után „áhitattal hangzott fel a Himnusz a sokezer fönyi közönség ajakán. ” A magyarság iránti lojalitás, a zsidó vallású magyar identitás bizonygatása jól tükröződik a cikk szellemében. Uo. 2-3.

${ }^{33}$ Vidor Pál: A budai zsidóság nagy cserkészhete. Egyenlöség, 1934. 25. 24.

REGIO 27. évf. (2019) 2. szám 105-126. 
legyetek, hanem azt: nem lehettek jó cserkészek, ha nem vagytok jó zsidók." 34

\section{Vidor és a cserkészpróbák}

A Magyar-Zsidó Szemle 1933-ban megjelent egyik számában Vidor Pál $A$ zsidó cserkész vallási ismeretei címen a gödöllöi világtalálkozó kapcsán közölt cikket. Másfél ezerre becsüli országosan a zsidó cserkészek létszámát. Sorsuk kell, hogy foglalkoztassa a Magyar Cserkészszövetséget is: „,..az $\sigma^{\prime \prime}$ elgondolásaik sem korlátozhatják a vallást egy bizonyos felekezetre vagy egynéhány kiválasztott felekezetre. "35 Vidor ennek értelmében a Magyar Cserkészszövetség Vezetötiszti Testületéhez fordult, hogy a Kiképzési Szabályzat egyes részeit módosítsák. A következőket javasolta: a „Szentlélek” szó helyére: „Isten”, ,, a keresztény helyébe pedig vallásos teendö, mert ez a megfogalmazás per definitionem kizárja a cserkészetböl a zsidófiúkat, de kizárja a mohamedán és egyéb vallásúakat is, ${ }^{36}$ akik pedig szintén nagy számban csatlakoztak a mozgalomhoz és akiket szintén cserkésztestvéri szeretettel kell fogadnunk és vendégül látnunk a gödöllöi Jamboreen. "37

A szabályzat valóban csak a katolikusok és a protestánsok számára tartalmazott útmutatást. ${ }^{38}$ Ezért indítványozta Vidor a Kiképzési

\footnotetext{
${ }^{34}$ Egyenlöség, 1934 54. évf. 25. szám, 24.

${ }^{35}$ Vidor Pál:A zsidó cserkész vallási ismeretei. Magyar-Zsidó Szemle, 1933, 5-8. 165 .

${ }^{36}$ Vidor Pál a cserkészetet iuxtakonfesszionális, egymás mellett megférő vallások mozgalmának nevezi:,,Nem katolikus, nem protestáns, nem mohamedán, de minden vallásnak megvan benne a létjogosultsága, egyiknek sem kell feladnia semmit sem hitelveiből.” L. Dr. Vidor Pál: A zsidó cserkészet (a zsidó ifjúság nevelésének egyik útja). In: Évkönyv, 1934. 40.

${ }^{37}$ Vidor, 1933. 165.

38 Kiképzési szabályzat: Vezetői utasítás: Tervezet / [közreadja a] Magyar Cserkészszövetség. Budapest: Magyar Cserkészszövetség, 1932, 32. A kiadványban „A cserkészet élése” (12. pont) a következő irányvonalakat tartalmazza [rövidítve - a szerz. megj.]:”A vallásosság nem valamelyik része a cserkészmunkának, hanem a napi jótett, a kirándulás, a tábor, a kiképzés nem más, mint az Úr Jézus gondolatai szerint rendezett élet. Krisztus a Király és mi a lovagjai."A katolikus cserkészek próbái után a protestánsok számára is megfogalmazódnak a próbapontok a III, a II. és az I. osztályú próbákban, pl.: „Az egész pont beállitottsága ne próbapont legyen. [...] Minden cserkészmunkád lehelje a mély vallásos meggyözödést, a hitet [..] Ne próbáztass tehát ebböl a
} 
Szabályzat $A$ cserkészet élése című fejezetének kiegészítését $A$ vallásosság alpontjai izraelita cserkészek számára címü dokumentummal, amely másfél oldalnyi terjedelemben halad próbáról próbára. Az első próba keretében például a következő követelményeket terjesztette elő a zsidó cserkész számára: „Kivülröl tudja a tíz igét magyarul s legalább kezdö szavait héberül, a hitvallomást (sömájiszróél) héberül és magyarul, ismeri az imarendet, az ünnepeket, azok jelentőségét és szertartásait." „A harmadik próba pedig a következö: „,...] Cserkészideált választ a zsidó történelemböl (pl. Mózes, Dávid, Júda Makkábi) és választását megindokolja". 39

A Tíz év a liliomos lobogó alatt címü - már idézett - jubileumi könyv állítása szerint Vidor törekvése, miután ahhoz az összes zsidó cserkészcsapat hozzájárult, megvalósult. Javaslatait állítólag a M. Cs. Sz. Országos Vezetötiszti Testülete elé terjesztették, ,kérve, hogy a katolikus és protestáns cserkészek vallási útmutatásai mellett vegyék föl azt is a Kiképzési Szabályzatba, valamint a Temesi Gyözö-féle Cserkészkönyvbe. E szerint a tervezet szerint, amelyet a központ éppen az utolsó napokban szabályzattá tett és kiadott, folyik csapatunkban a vallási kiképzés...". 40 1933/34-ben tehát megvalósult volna Vidor kezdeményezése. Mivel azonban a Kiképzési Szabályzat utolsó példánya 1933-ban jelent meg az 1932-es kiadvánnyal azonos terjedelemben, továbbra is csak tervezetként, így abba nem kerülhetett be Vidor útmutatása. ${ }^{41}$ Bár a Temesy Győző-féle Cserkészkönyvet

próbapontból, csak gyöződj meg az állandó és rendszeres éléséröl. Kivánd meg, hogy istentiszteletre legalább vasárnaponként önként és jókedvéböl járjon, vagy helyette vegyen részt a csapat áhitatain [...]”, „[...] ismerje egyháza elöljáróit, protestáns ünnepeket és azok jelentöségét" [...] 28/29. Az első osztályú próbában: „Ismeri a Bibliát (Az Uj- Testamentumot és azonkivül föleg a Zsoltárok könyvét [....] Életének zsinórmértéke az Evangélium [...]" 29.

${ }^{39}$ Vidor, 1933. 166.

${ }^{40}$ Tíz év a liliomos lobogó alatt. A Budai Izraelita Hitközség "Vörösmarty” cserkészcsapatának története 1924-1934. Budapest: Fáklya, 1934. 40.

${ }^{41}$ A Kiképzési Szabályzat 1932-es változatát cserkész ismerösök segítségével sikerült ugyan kézbe venni, az 1933-as, kétségen kívül változatlan kiadás nem került elő, mivel ezeket a szabályzatokat sem a magyarországi könyvtárak, sem a levéltárak nem őrizték meg. - A szerző megj.

REGIO 27. évf. (2019) 2. szám 105-126. 
1935-ben, egy évvel később adták ki utoljára, a zsidó cserkészek számára készült útmutatóba sem került be. ${ }^{42}$

Vidor további tervei nyomán a Cserkészkönyvbe még további gyakorlati vallási tudnivalókat is be kellett volna illeszteni, illetve külön Zsidó cserkészkönyv megjelentetését is tervezte. Ezt csaknem saját erejéből meg is valósította az 1938-ban, a szerzői kiadásként közreadott: A zsidó cserkész első próbája címü munkájával. ${ }^{43}$ Vidor tegezve szól a cserkészjelöltekhez, akik „emberebb ember és magyarabb magyar"-ok szeretnének lenni. Ennek szigorúan vett feltétele a vallás: „, Gondold meg azonban, hogy emberebb ember csak akkor lehetsz, ha él benned a valláshoz való hüség. "44

A továbbiakban Vidor azokat a gondolatokat fogalmazta meg újra, amelyek az Egyenlöség hasábjain korábban már megjelentek, így például Hillél tanítását, kiemelve a zil, gömor, 'menj és tanulj tovább' tanítást, vagyis azt, hogy a hittanóra a cserkész számára kevés, ezért folyamatosan tanulva egész héten át igyekezzék zsidó lenni. ${ }^{45}$ „, $A$ vallásosság beleárad és belesugárzik a csapat egész életébe és munkájába." A cserkészotthon is csupa zsidó szimbólummal legyen tele: ,Cserkészotthonunkban minden falat, minden sarkot vallásunk jelképei díszitenek. Itt menóra áll, ott kettös kötábla emelkedik ki, amott ismét mógén dóvid (Dávid pajzsa) foglalja magába az örs jeligéjét. A tíz törvény mellöl a szináji tíz ige tekint ránk s a jó munkát mellett a cházák veemác (légy erös és szilárd) bibliai köszöntés fogad. " 46

Külön könyvbe rendezve a vallási tudnivalókat már szabályos hittankönyvvé válik Vidor Pál szövege. A cserkészet inkább csak ürügyül szolgál. A korábbiakban elszórtan közölt, rövid, lelkesedéstől átitatott cikkek élettelenebb, didaktizált, megmerevedett változatában a szerző kendőzetlenül a hittant szeretné - igen magas színvonalon szétsugározni. A két kőtábla igéinek magyarázata, majd a zsidóság bibliai története, az egyes ünnepek a legnagyobb részletességgel szerepelnek a kötetben. Alig egy-egy rövid bekezdésnyi utalást

\footnotetext{
${ }^{42} \mathrm{~A}$ cserkészet eredetileg nem volt vallásos szervezet, Baden Powell az alattvalói hüségre épített. A magyar cserkészszövetség azonban vallási alapokra helyezte elveit.

${ }^{43}$ Dr Vidor Pál: A zsidó cserkész első próbája. Budapest: Szerző kiadása,1938.

${ }^{44}$ Uo. 3.

45 Uo. 4.

${ }^{46}$ Uo.. 6.
}

REGIO 27. évf. (2019) 2. szám 105-126. 
olvashatunk az adott vallási elöírás cserkészekre vonatkozó megvalósításáról: a gödöllői világtalálkozóra visszatekintve a héber nyelv nemzeteken átívelö, közösséget teremtő erejéröl, a szombat apropóján pedig a tábori istentiszteletről, majd az őszi bünbánati hetekhez füződve a cserkész számára kötelező lelkiismeretvizsgálatról $1{ }^{47} \mathrm{~A}$ zsinagógai év kapcsán, ${ }^{48}$ a kiadvány befejezéséül egyetlen, zárójelbe tett mondat vonatkozik a cserkészekre, mintegy fölszólítva őket a vallási ünnepek pontos követésére, a szombat betartására: Minden cserkésznek legyen luáchja ${ }^{49}$ Vidor Pál törekvései tehát a „Vissza a valláshoz” jegyében állnak leginkább. ${ }^{50}$

\section{Cionra tekintő szemek?}

Mennyire tekinthető cionista beállítottságúnak a Vörösmarty cserkészcsapat és abban Vidor tevékenysége? Támpontul szolgálhat a kérdéshez a budai hitközség és a Pro Palesztina Szövetség kapcsolatának feltárása. A Pro Palesztina létrehozásában ugyanis kulcsszerepet játszott a Budai Izraelita Hitközség elöljárósága és annak elnöke, a cserkészetet pártfogoló Baracs Károly. ${ }^{51}$ A mozgalom céljai nem voltak azonosak a cionizmus törekvéseivel. A Pro Palesztina a Palesztina-építés mellett a diaszpórán belüli zsidó élet és

\footnotetext{
${ }^{47}$ Uo. 15.; 19.; 23-24.

${ }^{48}$ A zsinagógai év ünnepeiről Vidor Pál más, cserkészettel kapcsolatos írásaiban is megemlékezik: A fák újéve, az ómerszámlálás napja, a hanuka mind megünnepelendők. „A chanukka - lángok nemcsak isteni csodáról, de emberi nagyságról, tiszta lobogóval, zsoltáros énekkel harcba induló makkabeus hösökröl, Istenünk iránti kötelességeiket hiven teljesitö „,cserkészekröl” is regélnek." Sőt, a cserkészfiúk barátaikat, nem cserkész társaikat is meghívhatják otthonaikba hanukai gyertyagyújtásra. Dr. Vidor Pál: A zsidó cserkészet (a zsidó ifjúság nevelésének egyik útja) In: Évkönyv,1934. 44.

${ }^{49}$ Uo. 31. Luáh: zsidó naptár

50 Ezt támasztja alá a külön kötetben kiadott A Szombat könyve. Vidor a bevezetőben kifejti, hogy sem vallási, sem nemzeti zsidóság nem képzelhető el szombat nélkül. Könyvének célja, hogy megéreztesse a legfontosabbat, a „sábbát mézét és illatát." Vidor Pál: A Szombat könyve. Budapest: Magyar Zsidók Pro Palesztina Szövetsége, 1942. 8.

${ }^{51}$ Baracs Károly 1921-től 1926-ig volt a hitközség elnöke. Felesége, Baracs Károlyné azonban a 1930-as években is aktív tagja volt a Budai Izraelita Hitközség Nőegyletének.
} 
érdekképviselet szorgalmazását is fontosnak tartotta. A két szervezetnek voltak közös tagjai, például Patai József. ${ }^{52}$ Baracs Károly elgondolásában a haza iránti töretlen hüség és a Szentföld iránti érdeklődés nem jelentett dilemmát. ${ }^{53}$

A 311-es Vörösmarty cserkészcsapat idős túlélőivel készített interjúk tovább árnyalhatják a képet. Bak János professzor, egykori cserkész szerint a csapatot a „burkolt cionizmus” jellemezte: „egy ifjúsági csapat, amelyik ugyan 'vallási' alapon áll össze, de nem vallásossággal, hanem testedzéssel, erkölcsi és kulturális neveléssel foglalkozik, automatikusan zsidó 'nemzetségi' jelleggel bír-ami csak egy lépés a cionizmus felé a gettó-, ill. zsinagóga-zsidósággal kvázi szemben ...". ${ }^{54}$ Ugyanakkor hozzátette, hogy új héber cionista dalokat nem énekeltek 1945 elött: „Hogy 1944-ben voltak, akik cionista földalatti ellenálláshoz tartoztak, azt csak hallottuk, mások - az öregcserkészek közül, ugyanigy magyar antifasiszta vagy kommunista csoportokhoz. Felszabadulás után egy páran tudtommal átmentek a Somérokhoz vagy a Makkabihoz - és tovább is Palesztinába, de azt én már nem követtem. "55

Bak a csapat társadalmi összetételére utalva említi, hogy nem csak a maga fajta gimnazista úrigyerekek voltak tagok, hanem akadtak bőven tanonc-, polgári iskolás alsó-középosztálybeliek is. Bak feltételezése szerint ők talán vallásosabbak is lehettek, vagy éppen talán cionista szimpatizánsok is:,,Mennyire keveredtek? Nem tudom. Valójában csak a saját örsünket (8-10 fiú vagy lány), legfeljebb részben a rajunkat (30-40 fö) ismertük közelebbröl... (...) Másrészt voltak keresztény, ill. kikeresztelkedett tagok is a csapatban. Esetleg emlithetö, hogy az utolsó - 1944. 03.19-re tervezett és sajnálatos események miatt elmaradt - éves hadijáték történelmi kerete a Bar Kochba felkelés volt/lett volna. Az elötte való években a königgrätzi csata meg a trójai háború stb. volt a téma. Hogy a militáns zsidó

52 Schweitzer Gábor: Vigyázó szemetek Cionra vessétek 2. Nézetek a magyarországi cionista mozgalomról a két világháború közötti zsidó sajtóban. Szombat, 1994. január 1. https://www.szombat.org/archivum/vigyazo-szemetekcionra-vessetek-ii

${ }^{53}$ Schweitzer,1994-re hivatkozik: Baracs Károly: Pro Palesztina. Múlt és Jövö, 1928. július-augusztus. 244.

${ }^{54}$ Gombocz Eszter beszélgetése, majd levelezése Bak Jánossal 2019 áprilisában. ${ }^{55}$ Uo.

REGIO 27. évf. (2019) 2. szám 105-126. 
ellenállás került a napirendre, talán elárul valamit az asszimiláció sikertelenségének beismeréséröl és a 'implikált' cionizmusról? "56

Mit árulnak el a dalok, amelyeket a táborokban énekeltek? Bak János A 311. Vörösmarty cserkészcsapat folklórjából ${ }^{57}$ címü füzetében említ néhány példát ,a kevés zsidó magyar hagyományról” a csapat folklórjában, köztük a „Szól a kakas már” címủ dalt, amelyet Vidor Pál többször is megemlít. Ezen kívül Bak a csapatindulót is megnevezi, amelyet himnuszként, ünnepélyes alkalmakkor énekeltek, de „, a mi generációnk már nemigen”.,,A csapat korábbi vezetői, gondolom, tudták, hogy honnan vették át. " 58 Bak János itt a Kadimah örökségére, a dal cionista eredetére céloz. A Kezét fel az égre ki férfi, ki bátor kezdetü ének az első magyarországi zsidó sportegyesület, a VAC indulója volt. Bak megjegyzi, hogy utolsó sorát - ,visszafizetjük a szolganyomort" - ifjú pacifistaként nem szerették énekelni, illetve nem is tudták, hogy mit kellene visszafizetniük. ${ }^{59}$

Fontos adalék, hogy a Fáklya újságban megjelent müsor szerint az 1930 december 21-i hanuka-ünnepségen a csapat elsőként a Hatikva (jelentése: A remény) címü dalt énekelte el közösen. ${ }^{60}$ Gerő Zsolt, a háború után újjáélesztett Vörösmarty csapat 90 éves összetartója 2019-ben megerősítette a himnusz továbbélését: „Szent áhitattal, héberül énekeltük. Nem is tudtuk, mi az. Belsö himnuszunk volt. Föleg táborokban, ünnepeken énekeltük. Ünnepi dal volt."61 A Kadimah egykori cionista, nemzeti identitású himnusza tehát, amelyet a csapat

\footnotetext{
${ }^{56}$ Gombocz Eszter interjúja Bak Jánossal, 2019. április.

${ }^{57}$ Bak János: A 311. Vörösmarty cserkészcsapat folklórjából. Alapításának 90. évfordulójára. Budapest, 2014. A megőrzött, rekonstruált dalok szövegét 2001ben az internetre is feltöltötték: http://www.mbarnett.com/v311/dalok.htm

${ }^{58}$ Uo. 2. Bak János szerint saját gyüjtése az 1939 utáni, föleg az 1940-es évek dalanyagát tartalmazza.

59 Uo. 3.:,,Hogy bárhova vessen és üzzön a végzet,/ Lerázzuk magunkról a szolganyomort / Hogy bárhova vessen és üzzön a végzet, /Mi visszafizetjük a szolganyomort!”. Szintén a Kadimah örökségéböl élt tovább a „Elöre cserkész mindig elöre" címü dal. Érdekes még a „Tíz kicsi szerecsen” jiddis variánsa, a „Zehnerige Brider" jiddis variánsú visszaszámláló bekerülése a csapat repertoárjába.

${ }^{60}$ A dal, amely később Izrael himnuszává vált, 1878-ban született, szerzője Naftali Herz Imber, aki 1882-ben érkezett Palesztinába. A dal a zsidó nép abbéli reményét fejezi ki, hogy egy napon visszatérhet ősei földjére, ahogy az a Bibliában megjövendöltetik. Cion itt Izrael/ Jeruzsálem szinonimája.

${ }^{61}$ Gombocz Eszter beszélgetése Gerő Zsolttal, 2019. május.
}

REGIO 27. évf. (2019) 2. szám 105-126. 
1925-től a Magyar Cserkészszövetség iránti lojalitás bizonyítása, és egyszersmind tagfelvétele kedvéért, $^{62}$ de egyben talán újfajta identitásként leváltott a Himnuszra és a Szózatra, még a 1930-as évek végén is élt a tagok emlékezetében. ${ }^{63}$

Tanulságos végigtekinteni a csapat névadó hősein is. A Tíz év a liliomos lobogó alatt címü kis kötet őket állítja példaképül a cserkészek elé. Míg Vidor Pál más írásaiban bibliai zsidó hősöket idéz, addig a jubileumi kötetben Vörösmarty, a csapat névadója, a Szózat szerzője válik a kitartás példaképévé. ${ }^{64}$ Vidor szónoki fogásként ötször szólítja meg a zsidó cserkészeket: „Vörösmarty cserkész! .... Soha ne csüggedj! Soha ne hátrálj!...” A kitartás egyrészt a hüséget fogadott zsidó cserkészeknek a magyarság melletti elköteleződésére szólít fel: ,...gondolj arra, aki azt mondotta: »Hazádnak rendületlenül légy hive, oh magyar«", másrészt a zsidóságot ért sérelmekre is céloz. A rövid cikk befejező sorai szinte sulykolják, hogy Vörösmarty szellemében hinni kell egy jobb kor eljövetelében, a zsidóságot ért megkülönböztetés megszünésében: „Ha meginogtunk is egy pillanatra, most már érezzük, hisszük és tudjuk: nem marad örök a sötétség. Még jönni fog, mert jönni kell egy jobb kor ..." 65

A rajok névadói - dr. Dömény Lajos, Lőw Lipót, Herzl Tivadar és Baracs Károly - a magyar zsidóság kiemelkedő alakjai. Herzl neve az egész világon egyet jelent a cionizmussal, de Magyarországon Dömény élete is elválaszthatatlan attól.

\section{Vidor elveinek fogadtatása}

A zsidó cserkész első próbája címen a Libanon hasábjain rövid méltatás jelent meg Takács Pál tollából. ${ }^{66}$ Eszerint Vidor könyve hiánypótló, hiszen a cserkészvezetők többsége laikus, és ezért rászorul

\footnotetext{
${ }^{62}$ A Magyar Cserkészszövetség csak vallási (nem pedig etnikai) identitás alapján tolerálta a zsidó csapatokat.

${ }^{63}$ A 2004-ben megjelent gyüjteményben viszont már nem szerepel a dal. A héberül énekelt, átszüremkedett szöveg, jelentését vesztve kitörlődhetett a többség aktív memóriájából.

${ }^{64}$ Tíz év a liliomos lobogó alatt. A Budai Izraelita Hitközség „Vörösmarty” cserkészcsapatának története 1924-1934. Budapest: Fáklya, 1934. 12.

${ }^{65}$ Uo. 12.

66 Takács Pál: A zsidó cserkész első próbája. Libanon, 1938. 133-134.
}

REGIO 27. évf. (2019) 2. szám 105-126. 
a könyvre. Takács elismeri, hogy alig néhány rész kapcsolódik a cserkészethez, de ez nem a szerző és nem is a zsidó cserkészet hibája, hanem annak tudható be, hogy a zsidó vallási tudnivalókról nem született más, az oktatást segítő összefoglaló munka. A bírálatból arra következtethetünk, hogy a vallás iránti igény mérsékeltnek mondható a neológia körében.

Megjegyzendő még, hogy a kiadvány megjelenését, ahogy azt a kötet legvégén utólagos megjegyzésként megtudhatjuk, csupán Vidor belső köre, a Budai Izraelita Hitközség és a miskolci 791. számú Dávid király cserkészcsapat támogatta. Más budapesti zsidó csapat nem vállalt részt a könyvecske megjelenésében. Feltételezhetően vagy nem tudtak azonosulni a vallás cserkészeten keresztüli érvényesítésével, vagy nem tartották időszerünek a vallási tudnivalók részletes ismertetését.

Vidor zsidó cserkésznövendékei is csak mérsékelten, a szekularizáció térnyerésével pedig egyre kevésbé követték rabbijuk vallásosságát. Egy túlélő cserkész szerint: „Kaba [Schächter Imre] kierőszakolta a vallásos magatartást. "67 A Bagoly őrs 1943. áprilisi Peszach naplója is arról tanúskodik, hogy a vallást nem kellett túl komolyan venni. ${ }^{68}$ A csapat túlélö szemtanúi sem emlékeznek a vallási elöírások szigorú betartására. Gerő Zsolt, aki 2019-ben ünnepelte 90. születésnapját, így értelmezi az általa tisztelt és szeretett vezető vallásosságának fogadtatását a Vörösmartyban: „Asszimilálódott zsidógyerekek voltunk, nem volt vallási áhítat köztünk. Az adott rajvezetö, örsvezetö hozott vallási szintjétől függött, hogy mit adott át. A táborban volt imaidö, de az én vezetöm nemigen imádkozott velünk. Vidor lehet, hogy nagy eröfeszitéseket tett, de ez az áhítat nem tudott átültetödni. "69

${ }^{67}$ A 311.Vörösmarty cserkészcsapat 1934-1938. Emlékek-emlékképek. 2004.33. ${ }^{68}$ Uo. Pészach túrai szabályok (Bagoly őrs naplója, 1943 április 22-24, 57.):, $A$ pészach-túra elött az egész lakást a házigazda személyesen átkutatja, hátha valamilyen kaját [héber betűvel] elfelejtettek a G.H. ['Gazdasági Hivatal'. Héber betüvel] -nak átadni. Afikománnak, vagy zugkajának nevezik azt, mikor valaki eldug magának valamilyen ennivalót a g.h elöl. Ezt a többiek megkeresik, és ha megtalálják, az eldugó ruhát kap."

${ }^{69}$ Gombocz Eszter beszélgetése Gerő Zsolttal, 2019. május.

REGIO 27. évf. (2019) 2. szám 105-126. 
Annál inkább említik az ún. túlélő erőpróbákat, amelyeknek köszönhetően életben maradtak. ${ }^{70}$ Bizonyára torzíthat az emlékezet is, hiszen a jelenből tekintve az edzés, az állóképességre nevelés, az összetartás, a szolidaritás volt a humor mellett a cserkészet legfőbb ereje. A vallás utolsó nyomainak elvesztése a Soá után többeknél szintén hozzájárulhatott a háború elötti identitás módosult megítéléséhez.

\section{Összefoglalás}

Tanulmányomban a két világháború közötti asszimilációs/disszimilációs stratégiák vázlatos ismertetése mentén a 311-es Vörösmarty cserkészcsapat tudós rabbijának, dr. Vidor Pálnak a cserkészethez, mint ifjúságnevelési módszerhez füződő viszonyát vizsgáltam. Vidor vajon mint fiatal, tehetséges, a gyerekek szavát értő nevelő lelkesedett a cserkészetért, vagy elsősorban a zsidó vallást próbálta érvényesíteni a cserkészeten keresztül? Netán a zsidó nemzeti identitást igyekezett a fiatalokban erősíteni? „Nochdazu” cionista volt lelke mélyén?

A vizsgált szövegek arra vallanak, hogy Vidor számára a zsidó vallási és kulturális identitás, a „zsidó érzés” újjáélesztése, továbbörökítése volt az elsődleges szempont. Bár tudott a nehézségekröl (zátonyra futó asszimiláció/diszkrimináció/szekularizáció), idealista hajlamú nevelő lévén mégis hitt a zsidó-magyar békés együttélés fölélesztésének lehetőségében. Már rabbivá avatása előtt maga köré gyűjtött egy zsidó értelmiségi magot, majd a cserkészeten keresztül a fiatalabb generációt is megnyerte céljainak. A zsidó cserkészet átmenetileg - valóban rugalmas, oltalmat nyújtó közösségi keretet biztosított az identitásában elbizonytalanodott fiatalok számára.

\footnotetext{
${ }^{70} \mathrm{Az}$ egyik leghatásosabb lélektani és nevelési módszer a hékli volt. A vezetők olyan történetet találtak ki, amelyek gyors reagálásra, a félelem leküzdésére ösztönözték a gyerekeket. A 40-es években többször is eljátszották, hogy az éjszaka közepén csendőrök vagy nyilasok támadnak a táborlakókra. Ezek az ugratások, a súlyos hátizsákok cipeltetése az állóképesség növelésére a vezetök tudatos elörelátására vallanak a fokozódó antiszemitizmus légkörében. Vö. $A$ 311.Vörösmarty cserkészcsapat 1934-1938. Emlékek - emlékképek. 2004. 40.; Továbbá: Gombocz Eszter: Zsidó iskolások. http://zsidoiskolasok.tk.mta.hu (pl. Gerő Zsolt emlékezése)
}

REGIO 27. évf. (2019) 2. szám 105-126. 
Vidor Pál életének egyik legmeghatározóbb élménye az 1933-as gödöllöi világtalálkozó volt, amelyre hosszasan készülődött. Nagyon sokat, talán túlontúl sokat is várt a jamboree-tól. A világtalálkozó alkalmat teremtett arra, hogy a zsidó cserkészek befelé és kifelé egyaránt bizonyítsák magas fokú judaisztikai tudásukat, müveltségüket, büszke, mások iránt nyitott identitásukat. Vidor elképzelései részben valóra váltak, hiszen magyar tervező által elkészült a zsidó cserkészek tábori oltára, ahol ő mondhatta el több nemzet képviselői előtt a nyitó beszédet. A tábori előkészületek keretében remélte a Kiképző Szabályzat zsidó vallási ismeretekkel bővített módosítását is, ami azonban szinte egészen biztos, hogy nem valósult meg. Nyitott, elöítéletektől mentes, a világot jobbítani akaró személyisége nem gyanította, hogy a világtalálkozó toleráns szelleme inkább külpolitikai fogás Horthy Magyarországán.

A Vörösmarty cserkészcsapat cionista „beütése” egyrészt a Kadimah öröksége, másrészt önerősítő, zsidó etnicista stratégiára vall, amely nem vált a zsidó-magyar együttélést megtagadó egységes disszimilációs törekvéssé. A csapat tagsága, hasonlóan a magyarországi zsidóság legnagyobb részéhez, nem tudta elképzelni végső kitaszítását, elárulását. Bár bizonyosan voltak, akik közelebb álltak a cionizmus eszméihez (például Hajdú László), a legtöbben bíztak a zsidó-magyar együttélés fönntarthatóságában, hiszen a diszkrimináció erősödése aránylag lassan, lépésről lépésre, illetve felemásan, következetlenül, egymásnak gyakran ellentmondó szándékok mentén érvényesült a cserkészeten belül is. ${ }^{71}$ Magyarország jobbra tolódásával azonban egyre határozottabbá vált a zsidó csapatok kirekesztése.

1941-ben másokkal együtt kizárták a Vörösmarty csapatot is a Magyar Cserkészszövetségből, így ezentúl a Budai Izraelita Hitközség égisze alatt müködhetett csak tovább. A cserkészek összetartottak, még 1943-ban is alakult új csapat, a falkák 110-en voltak. Mindeközben munkaszolgálatra hívták a cserkészvezetőket is. Dr. Vidor Pál 1942-ben vonult be Billitzer Ernő fökántorral, Parczel Sándor jegyzővel együtt a Zsigmond király útja 49. számú házból, ahol a Vörösmarty csapat cserkészotthona és a Vidor Pál által

\footnotetext{
${ }^{71}$ L. ehhez a tematikus blokk erre vonatkozó tanulmányát, Vörös Kata: Numerus clausustól a numerus nullusig - A zsidó cserkészek kirekesztése a Magyar Cserkészszövetségböl.
}

REGIO 27. évf. (2019) 2. szám 105-126. 
kezdeményezett izraelita elemi iskola müködött. Egyikük sem tért haza soha többé. ${ }^{72}$

\section{Felhasznált irodalom}

Bagoly őrs naplója, 1943. április 22-24. In: Bánki György - Gerö Zsolt, szerk.: A 311. Vörösmarty cserkészcsapat 1934 - 1938. Emlékek - emlékképek. Budapest: A 311. Vörösmarty Cserkészcsapat Öregcserkész Klubja, 2004.

Bak János: A 311. Vörösmarty cserkészcsapat folklórjából. Alapitásának 90. évfordulójára. Budapest: [szerzői kiadás], 2014.

Bánki György - Gerő Zsolt (szerk.): A 311. Vörösmarty cserkészcsapat 1934 - 1938. Emlékek-emlékképek. Budapest: A 311. Vörösmarty Cserkészcsapat Öregcserkész Klubja, 2004.

Benoschofszky Imre - Vidor Pál (szerk.): Évkönyv. A Budai Izraelita Hitközség Kulturális Szakosztálya Ifjusági Csoportjának 1930/31 évi müködéséröl.Budapest: Phoebus Nyomda, 1931.

Benoschofszky Imre - Vidor Pál (szerk.): Évkönyv. A Budai Izraelita Hitközség Kulturális Szakosztálya Ifjusági Csoportjának 1933/34 évi müködéséröl. Budapest: Phoebus Nyomda, 1934.

Benoschofszky Imre - Vidor Pál (szerk.):Évkönyv. A Budai Izraelita Hitközség Kulturális Szakosztálya Ifjusági Csoportjának 1936-38 évi müködéséről. VII-VIII. Budapest: Phoebus Nyomda, 1938.

Frojimovics Kinga: Szétszakadt történelem.Zsidó vallási irányzatok Magyarországon 1868-1950. Budapest: Balassi Kiadó, 2008.

Gombocz Eszter: Zsidó iskolások. http://zsidoiskolasok.tk.mta.hu

\footnotetext{
72 Sorsuk alakulásáról a sok helyen idézett $A$ 311. Vörösmarty cserkészcsapat 1934-1938. Emlékek - emlékképek címü kiadványból értesülhetünk. Dr. Vidor Pál halálának körülményeihez Sirota Sándor budai kántornak mint szemtanúnak a vallomása nyújt adalékot. Eszerint Vidor bár megszökhetett volna a Buchenwald felé vezető úton, rabbiként azonban nem akarta cserbenhagyni társait. Sirota szerint dr. Vidor Pált Buchenwald felszabadítása előtt egy nappal lőtték agyon más gyöngélkedőkkel együtt. Vö. A 311. Vörösmarty cserkészcsapat 1934-1938. Emlékek-emlékképek. 2004. 24.
}

REGIO 27. évf. (2019) 2. szám 105-126. 
Hrotkó Larissza: Vidor Pál ürügyén. „A Chóréb ormán”. Remény, 2007. 2. 53.

Kiképzési szabályzat. Vezetöi utasitás. Tervezet. Budapest: Magyar Cserkészszövetség, 1932. (Cserkészszabályzatok 3.)

Munkácsi Bernát: Az izraelita vallásoktatás újabb országos rendezésének elömunkálatai. Budapest, 1930.

Rajhíradó. Kézirat gyanánt. Kiadja a 311. sz. Vörösmarty cserkészcsapat I. raja. 1929/30 - 1930/31. [A címlapon „dr. Vidor Pál rabbi Budapest" feliratú pecsét, és Vidor Pál saját kezü aláírása, alatta kézzel írott évszámmal: 1932.]

Schweitzer Gábor: Vigyázó szemetek Cionra vessétek 2. Nézetek a magyarországi cionista mozgalomról a két világháború közötti zsidó sajtóban. Szombat 1994. január 1. https://www.szombat.org/archivum/vigyazo-szemetek-cionravessetek-ii

Szabolcsi Lajos: A zsidó cserkészek a gödöllői világtáborban. Egyenlöség, 1933. 41. 1-2.

Szabolcsi Lajos: Péntekesti istentisztelet a gödöllői park fái alatt. Egyenlöség, 1933. 42. 1.

Takács Pál: A zsidó cserkész első próbája. Libanon, 1938, 133-134.

Temesy Győző: Magyarország története cserkészek számára. Budapest: Magyar Cserkészszövetség, 1928.

Tíz év a liliomos lobogó alatt. A Budai Izraelita Hitközség „Vörösmarty” cserkészcsapatának története 1924-1934. Budapest: Fáklya,1934.

Vidor Pál: „Szól a kakas már...” a tábortüz mellett. A zsidó cserkészek táborozása.Egyenlöség, 1932. 42. szám, 6.

Vidor Pál: A budai zsidóság nagy cserkészhete. Egyenlöség, 1934. 25. 24.

Vidor Pál: A gödöllői táborozás. Seregszemle a jamboree előtt. Egyenlöség,1933. 39. 11. 
Vidor Pál: $A$ zsidó cserkész elsö próbája. Budapest: [szerzői kiadás],1938.

Vidor Pál: A zsidó cserkész vallási ismeretei. Magyar-Zsidó Szemle, 1933/5-8. Morija-melléklet, 164-168.

Vidor Pál: A zsidó cserkészet (a zsidó ifjúság nevelésének egyik útja). In: Vidor Pál: A Szombat könyve. Budapest: Magyar Zsidók Pro Palesztina Szövetsége, [5703 = 1942]. (Javne könyvek 8.)

REGIO 27. évf. (2019) 2. szám 105-126. 